\title{
The $\beta$-Carboline Alkaloid Harmol Induces Cell Death via Autophagy but Not Apoptosis in Human Non-small Cell Lung Cancer A549 Cells
}

\author{
Akihisa ABe, ${ }^{*, a}$ Hiroyuki Yamada, ${ }^{b}$ Shota Moriya, ${ }^{a}$ and Keisuke MiYazawA ${ }^{a}$ \\ ${ }^{a}$ Department of Biochemistry, Tokyo Medical University; 6-1-1 Shinjuku, Shinjuku-ku, Tokyo 160-8402, Japan: and \\ ${ }^{b}$ Bacteriology Division, Mycobacterium Reference Center, Research Institute of Tuberculosis, JATA; 3-1-24 Matsuyama, \\ Kiyose, Tokyo 204-0022, Japan. Received February 24, 2011; accepted May 18, 2011; published online May 24, 2011
}

\begin{abstract}
$\beta$-Carboline alkaloids are naturally occurring plant substances that have a wide spectrum of neuropharmacological, psychopharmacological, and antitumor effects. Recently, we have demonstrated that harmol, a $\beta$-carboline alkaloid, induces apoptosis by caspase-8 activation independently from Fas/Fas ligand interaction in human non-small cell lung cancer (NSCLC) $\mathrm{H596}$ cells. Here, we found that harmol induces autophagy and cell death in human NSCLC A549 cells. Although harmol induced cell death in A549 cells in a significant dose- and time-dependent manner, it did not induce caspase-3, caspase-8, or caspase-9 activity. Furthermore, cleavage of poly-(ADP-ribose)-polymerase was not induced in A549 cells by harmol treatment. Autophagy, but not apoptosis, was detected by electron microscopy in A549 cells treated with $70 \mu_{\mathrm{M}}$ harmol. Pretreatment of A549 cells with 3 methyladenine, an autophagy inhibitor, as well as small interfering RNA (siRNA)-mediated knockdown of LC3, both suppressed harmol-induced cell death. These suggest that the induction of autophagy by harmol precedes cell death. The cytotoxicity of some anticancer agents is reportedly linked to autophagy induction. The 2 major autophagy regulatory pathways are the Akt/mammalian target of rapamycin (mTOR) pathway and the extracellular signal-regulated kinase $1 / 2$ (ERK1/2) pathway. Although harmol treatment showed no effect on the Akt/mTOR pathway, it transiently activated the ERK1/2 pathway. However, inhibition of the ERK1/2 pathway using the mitogen-activated protein kinase (MEK)/ERK inhibitor U0126 partially suppressed autophagy. Therefore, although activation of the ERK1/2 pathway might be related to harmol-induced autophagy, another major pathway may also be involved in A549 cells.
\end{abstract}

Key words harmol; autophagy; extracellular signal-regulated kinase 1/2; Akt; mammalian target of rapamycin; human nonsmall cell lung cancer

Lung cancer is a leading cause of death worldwide, and the long-term survival rate of lung cancer patients is one of the lowest among cancers. ${ }^{1,2)}$ Two major types of lung cancer have been identified: non-small cell lung cancer (NSCLC) and small cell lung cancer (SCLC). NSCLC, the most prevalent subtype, is relatively resistant to chemotherapy and radiation therapy. On the other hand, SCLC is initially highly sensitive to chemotherapy and radiation therapy, but shows resistance to treatment in the majority of patients. ${ }^{3)}$ The high mortality in NSCLC is due to the difficulty of early diagnosis and its high potential for local invasion and distant metastasis. Although relatively effective chemotherapeutic agents have been developed, lung cancer still has a low cure rate. Furthermore, the adverse effects of chemotherapeutic compounds often hamper the quality of life of lung cancer patients. Therefore, the discovery of effective novel prophylactic, diagnostic, and therapeutic treatments for NSCLC is urgently needed.

"Apoptosis" has been used as a synonym for programmed cell death (PCD), and is a well-known form of PCD. Since the 1960s, various morphological forms of PCD have been recognized. Clarke classified cell death into 4 types, including type I PCD (apoptosis) and type II PCD (autophagy). ${ }^{4}$ Numerous studies have demonstrated that most chemotherapy agents and certain naturally occurring compounds induce cell death by activating the apoptotic pathway. It is thought that apoptosis induction in tumor cells with either drugs or natural products is effective therapy for cancer and immune system diseases. On the other hand, autophagy is one of the major regulatory mechanisms in the degradation of intracellular proteins and organelles. ${ }^{5,6)}$ During autophagy, the cytosol and whole organelles become encased in double-mem- brane vacuoles such as autophagosomes, and subsequently fuse with lysosomes. ${ }^{5)}$ Degradation of the sequestered material generates nucleotides, amino acids, and free fatty acids that are recycled for macromolecular synthesis and ATP generation. ${ }^{7)}$ Although originally characterized as a survival response to nutrient deficiency, autophagy is now recognized as frequently induced in response to a variety of stressors to maintain cellular homeostasis. ${ }^{8-12)}$ In recent years, the importance of autophagy has been emphasized in various biological fields, including cancer. ${ }^{9,13-15)}$ Furthermore, cancer cells show less autophagy than normal cells. ${ }^{16,17)}$ These findings indicate that autophagy induction is an attractive modality of anticancer therapy.

$\beta$-Carboline alkaloids occur in a number of medicinal plants such as Peganum harmala, Passiflora edulis, Passiflora incarnata, and Banisteriopsis caapi. ${ }^{18,19)}$ These plants have been used in traditional medicine to treat asthma, jaundice, lumbago, and other human ailments. ${ }^{19-21)}$ Recently, it has been reported that certain $\beta$-carboline alkaloids and their related compounds have cytotoxic effects on cancer cells. ${ }^{2-24)}$ We also reported previously that harmol, a $\beta$-carboline alkaloid, induces caspase-8-dependent and Fas/Fas ligand-independent apoptosis in human NSCLC H596 cells (adenosquamous carcinoma). ${ }^{25)}$

In the present study, we investigated the anticancer effects of harmol on human adenocarcinoma A549 cells in vitro. We also investigated the signal pathways of harmol-induced autophagy.

\section{MATERIALS AND METHODS}

Chemicals Harmol (purity, minimum 98\%) (Fig. 1), di- 


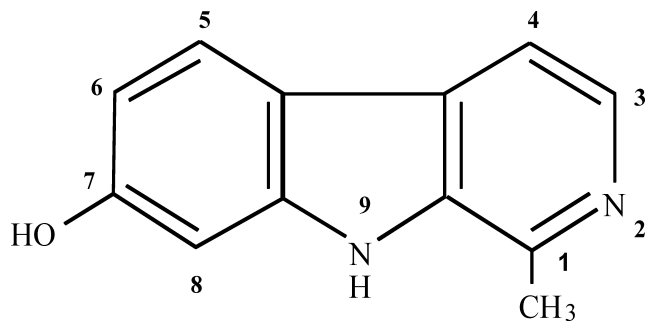

Fig. 1. Chemical Structure of Harmol

methyl sulfoxide (DMSO) and U0126, a mitogen-activated protein kinase (MEK)/extracellular signal-regulated kinase 1/2 (ERK1/2) inhibitor, were purchased from Wako Pure Chemical Industries Ltd. (Osaka, Japan). Harmol was dissolved in DMSO at a concentration of $200 \mathrm{~mm}$, and stored at $-20^{\circ} \mathrm{C}$ until use. Caspase substrates Ac-DEVD-7-amino-4trifluoromethyl coumarin (AFC) (caspase-3), Ac-IETD-AFC (caspase-8), Ac-LEHD-AFC (caspase-9) and the pan-caspase inhibitor z-VAD-FMK were obtained from MBL (Nagoya, Japan). Monodansylcadaverine (MDC) and 3-methyl adenine (3-MA) were obtained from Sigma Aldrich (St. Louis, MO, U.S.A.).

Cell Lines and Culture Condition Human NSCLC A549 (adenocarcinoma) cells were obtained from the American Type Culture Collection (ATCC) (Manassas, VA, U.S.A.). This cell line was cultured in RPMI-1640 medium (Wako) with $80 \mathrm{mg} / \mathrm{l} \mathrm{kanamycin} \mathrm{sulfate} \mathrm{(Wako)} \mathrm{and} \mathrm{heat-in-}$ activated fetal bovine serum (Biowest, Miami, FL, U.S.A.) and maintained at $37{ }^{\circ} \mathrm{C}$ in an incubator containing $95 \%$ air and $5 \% \mathrm{CO}_{2}$.

Cell Viability Cell viability was assessed with the CellTiter-Blue cell viability assay kit (Promega Corp., Madison, WI, U.S.A.). In viable cells, resazurin, which is contained in the CellTiter-Blue cell viability assay reagent, is metabolized to the fluorescent product resorufin. The tumor cells $\left(4 \times 10^{4}\right.$ cells/well $)$ were precultured in a 48 -well flatbottom microtiter plate overnight at $37{ }^{\circ} \mathrm{C}$ in a $5 \% \mathrm{CO}_{2}$ humidified chamber. Then, various concentrations of harmol were added and the cells were incubated for $24-48 \mathrm{~h}$. After incubation, $100 \mu$ lof CellTiter-Blue reagent (Promega) was added to each well and the cells were further incubated for $2 \mathrm{~h}$. After incubation, the medium of each well was analyzed using a Powerscan HT microplate reader (DS Pharma Biomedical Co., Osaka, Japan) at an excitation wavelength of $560 \mathrm{~nm}$ and an emission wavelength of $590 \mathrm{~nm}$. Cell viability was determined based on the fluorescence intensity of nontreated cells.

Assay for Caspase Activity Caspase activity was measured using fluorogenic peptide substrates. Both untreated control cells and cells which had been treated with $70 \mu \mathrm{m}$ harmol were washed with ice-cold phosphate-buffered saline (PBS) and suspended in lysis buffer [100 mm 2-[4-(2-hydroxyethyl)-1-piperazinyl] ethane sulfonic acid (HEPES), $\mathrm{pH} 7.5$, $150 \mathrm{~mm} \mathrm{NaCl}, 1 \%$ Nonidet P-40, $1 \mathrm{~mm}$ ethylenediamine$N, N, N^{\prime}, N^{\prime}$-tetraacetic acid (EDTA), $1 \mathrm{~mm}$ dithiothreitol (DTT), $1 \mathrm{~mm}$ phenylmethylsulfonyl fluoride (PMSF), $10 \mu \mathrm{M}$ leupeptin and $1 \mu \mathrm{M}$ pepstatin] for $30 \mathrm{~min}$ on ice, followed by centrifugation at $12000 \boldsymbol{g}$ for $10 \mathrm{~min}$ at $4{ }^{\circ} \mathrm{C}$. In total, $50 \mu \mathrm{g}$ of protein in $40 \mu \mathrm{l}$ of buffer solution was mixed with $10 \mu \mathrm{l}$ of $15 \mathrm{~mm}$ fluorogenic report substrate, for each individual cas- pase: Ac-DEVD-AFC for caspase-3, Ac-IETD-AFC for caspase- 8 and Ac-LEHD-AFC for caspase-9. The reaction mixture was added to $450 \mu \mathrm{l}$ of assay buffer [20 mM HEPES (pH 7.4), $0.1 \mathrm{M} \mathrm{NaCl}, 5 \mathrm{~mm}$ DTT, $0.1 \%$ Nonidet P-40], and incubated at $37^{\circ} \mathrm{C}$ for $1 \mathrm{~h}$. The enzymatic product AFC, which was released from the substrate, was excited at $400 \mathrm{~nm}$ to measure its emission at $505 \mathrm{~nm}$. Untreated cells were used as a control.

Visualization of Monodansylcadaverine-Labeled Vacuoles in Harmol-Treated A549 Cells A549 cells were treated with $70 \mu \mathrm{M}$ harmol for $0-12 \mathrm{~h}$ at $37^{\circ} \mathrm{C}$, and then treated with $50 \mu \mathrm{M}$ MDC for $10 \mathrm{~min}$. After treatment, cells were washed 4 times with PBS and immediately observed by fluorescence microscopy (BZ-8100, Keyence Co., Osaka, Japan).

Electron Microscopy Cultured A549 cells with and without $70 \mu \mathrm{M}$ harmol treatment were rinsed with phosphate buffer (PB) (0.1 M, pH 7.4). Cells were then fixed with $2.5 \%$ glutaraldehyde in PB for $3 \mathrm{~h}$ at $4{ }^{\circ} \mathrm{C}$, rinsed with $\mathrm{PB}$ for $5 \mathrm{~min}$ at least 3 times, and post-fixed with $1 \%$ osmium tetroxide for $1 \mathrm{~h}$ at $4{ }^{\circ} \mathrm{C}$, followed by dehydration in graded ethanol series for $5 \mathrm{~min}$ at room temperature (RT). After dehydration with absolute ethanol, cells were treated with a mixture of absolute ethanol and Spurr resin $(1: 1, \mathrm{v} / \mathrm{v})$ for $1 \mathrm{~h}$ at RT. Then, the mixture was replaced with pure Spurr resin and cells were treated for $1 \mathrm{~h}$ at RT, twice. The pellets were transferred to a Beem capsule, overlaid with new resin and subjected to resin polymerization at $70^{\circ} \mathrm{C}$ for $16 \mathrm{~h}$. Ultrathin sections were cut with Ultracut E (Reichert-Jung Co., Vienna, Austria), stained with uranyl acetate and lead citrate, and examined using a JEM-1230 transmission electron microscope (JEOL, Tokyo, Japan).

Western Blot Analysis Whole cell proteins were isolated from untreated and harmol-treated A549 cells. After treatment, the cells were centrifuged at $300 \boldsymbol{g}$ for $5 \mathrm{~min}$, and the pellet was lysed in a buffer containing $25 \mathrm{~mm}$ HEPES ( $\mathrm{pH}$ 7.4), $150 \mathrm{~mm} \mathrm{NaCl}, 0.5 \%$ Triton $\mathrm{X}-100,10 \%$ glycerol, $1 \mathrm{~mm}$ DTT, $1 \mathrm{~mm}$ sodium orthovanadate, $25 \mathrm{~mm} \beta$-glycerophosphate, $1 \mathrm{~mm} \mathrm{NaF}$ and $5 \mu \mathrm{l} / \mathrm{ml}$ protease inhibitor cocktail (Wako). The protein content of each lysate was determined using a BCA protein assay kit (Pierce Biotechnology Inc., Rockford, IL, U.S.A.). Protein lysates were then mixed with an equal volume of gel loading buffer ( $20 \%$ glycerol, $4 \%$ sodium dodecyl sulfate (SDS), $100 \mathrm{~mm}$ Tris, $5 \% \beta$-mercaptoethanol and $0.01 \%$ bromophenol blue) before being boiled for $5 \mathrm{~min}$. After boiling, $40 \mu \mathrm{g}$ of protein was subjected to SDS-polyacrylamide gel electrophoresis. Proteins were then transferred onto a polyvinylidene fluoride membrane (GE Healthcare U.K. Ltd., Buckinghamshire, U.K.). Blots were then blocked for $1 \mathrm{~h}$ at RT in 5\% non-fat dry milk diluted in Tris-buffered saline supplemented with $0.1 \%$ Tween 20 (TBS-T) (ICN Biomedicals Inc., Aurora, OH, U.S.A.). The following primary antibodies were incubated for $2 \mathrm{~h}$ at RT in TBS-T as follows: rabbit anti-poly-(ADP-ribose)-polymerase (PARP) (Cell Signaling Technology Inc., Danvers, MA, U.S.A., 1 : 1000), rabbit anti-Akt (Cell Signaling Technology, $1: 1000$ ), rabbit anti-phospho-Akt (p-Akt) (Cell Signaling Technology, 1:1000), rabbit anti-mammalian target of rapamycin (mTOR) (Cell Signaling Technology, $1: 1000$ ), rabbit anti-phospho-mTOR (p-mTOR) (Cell Signaling Technology, $1: 1000$ ), rabbit anti-70 $\mathrm{kDa}$ ribosomal protein S6 kinase 
(P70S6K) (Cell Signaling Technology, $1: 1000)$, rabbit antiphospho-p70S6K (p-P70S6K) (Cell Signaling Technology, $1: 1000)$, rabbit anti-eukaryotic translation initiation factor 4E-binding protein 1 (4E-BP1) (Cell Signaling Technology, $1: 1000)$, rabbit anti-phospho-4E-BP1 (p-4E-BP1) (Cell Signaling Technology, $1: 1000)$, rabbit anti-extracellular signalregulated kinase (ERK1/2) (Cell Signaling Technology, $1: 1000)$, rabbit anti-phospho-ERK1/2 (p-ERK1/2) (Cell Signaling Technology, $1: 1000)$, rabbit anti-microtubule-associated protein 1 light chain 3 (LC3) (Cell Signaling Technology, 1:1000), and mouse anti- $\beta$-actin (Sigma-Aldrich, $1: 3000)$. Peroxidase-conjugated secondary antibodies were incubated for $1 \mathrm{~h}$ at RT as follows: goat anti-mouse IgG (Jackson Immunoresearch Laboratories Inc., West Grove, PA, U.S.A., 1:5000) or goat anti-rabbit IgG (Cell Signaling Technology, $1: 2000)$. Blots were then washed with TBS-T and developed using Immobilon chemiluminescent substrate (Millipore Corp., Billerica, MA, U.S.A.).

LC3 siRNA Transfection For the gene silence of LC3 in A549 cells, LC3 small interfering RNA (siRNA) and control scramble siRNA, whose sequences are described below, were diluted to a final concentration of $20 \mathrm{~nm}$ in Opti-Mem I (Invitrogen Corp., Carlsbad, CA, U.S.A.), and transfection was performed with cells at $50 \%$ confluency using Oligofectamine transfection reagent (Invitrogen) according to the manufacturer's instruction. LC3 sense: 5'-CAAUCUCAGAGGUGUAUGTT-3'; LC3B antisense: 5'-UCAUACACCUCUGAGAUUTT-3'; control sense: 5'-GACUACUGGUCGUUGAACUTT-3'; control antisense: 5'-AGUUCAACGACCAGUAGUCTT-3'.

Real-Time Reverse-Transcription (RT)-Polymerase Chain Reaction (PCR) of LC3 Total RNA was isolated from cell pellets using Isogen (Nippon Gene, Tokyo, Japan) and genomic DNA was isolated using RQ1 RNase-Free DNase (Promega) at $37^{\circ} \mathrm{C}$ for $30 \mathrm{~min}$, followed by extraction using phenol, chloroform and ethanol precipitation. Reversetranscription using a PrimeScript RT Master Mix (Takara Bio, Inc., Shiga, Japan) was performed according to the manufacturer's instructions. Real-time PCR was performed on 3 ng of cDNA using validated SYBR Green gene expression assays for human LC3 in combination with SYBR Premix Ex TaqII (Takara Bio, Inc.). Primers used in this study were as follows: forward primer: 5'-CTTCTCACCCTTGTATCGTTCTATT-3'; reverse primer: 5'-CGCACCTTCGAACAAAGAG-3'. Quantitative real-time PCR was performed in duplicates in a Thermal Cycler Dice Real Time System TP800 (Takara Bio, Inc.). Data were analyzed using Thermal Cycler Dice Real Time System Software (Takara Bio, Inc.), and the comparative $\mathrm{Ct}$ method was used for relative quantification of gene expression. The data of real-time PCR products were standardized to glyceraldehyde-3-phosphate dehydrogenase (GAPDH) as an internal control.

Statistical Analysis Results are presented as means S.D. Statistical comparisons of the results were made using analysis of variance. A $p$ value of less than 0.05 was considered to indicate a statistically significant difference. Between the means of control and treated cells were analyzed by Dunnett's test.

\section{RESULTS}

Cytotoxic Effects of Harmol on A549 Cells Continuous treatment of human lung cancer A549 cells with harmol

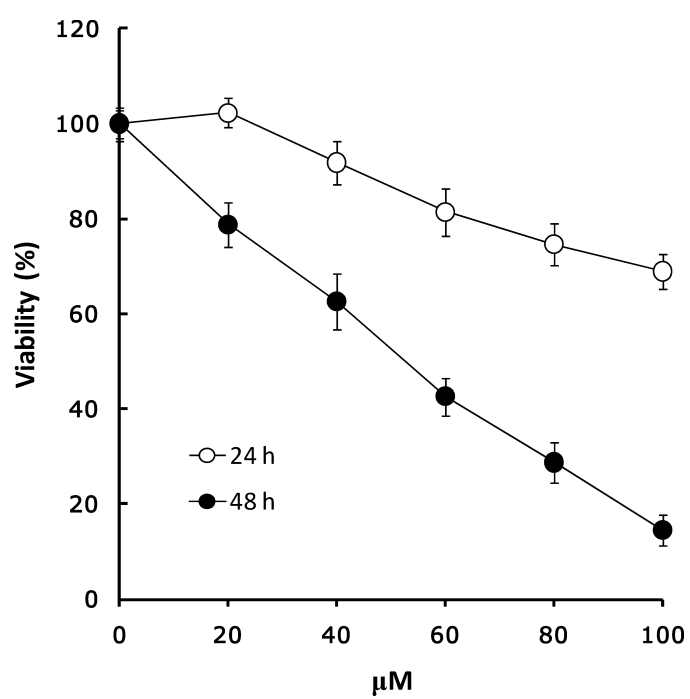

Fig. 2. Effects of Harmol Treatment on Human Non-small Cell Lung Cancer A549 Cells

A549 cells were treated with various concentrations of harmol for $24-48 \mathrm{~h}$. Control cells were treated with the same volume of DMSO as a vehicle alone (the final concentration of DMSO was below $0.1 \%$ ). After treatment, cell viability was measured by a CellTiter-Blue assay reagent as described in Materials and Methods, and then calculated as a percentage of viability of the control cells. The results of harmol treatment assays are presented as means \pm S.D. based on three independent experiments.

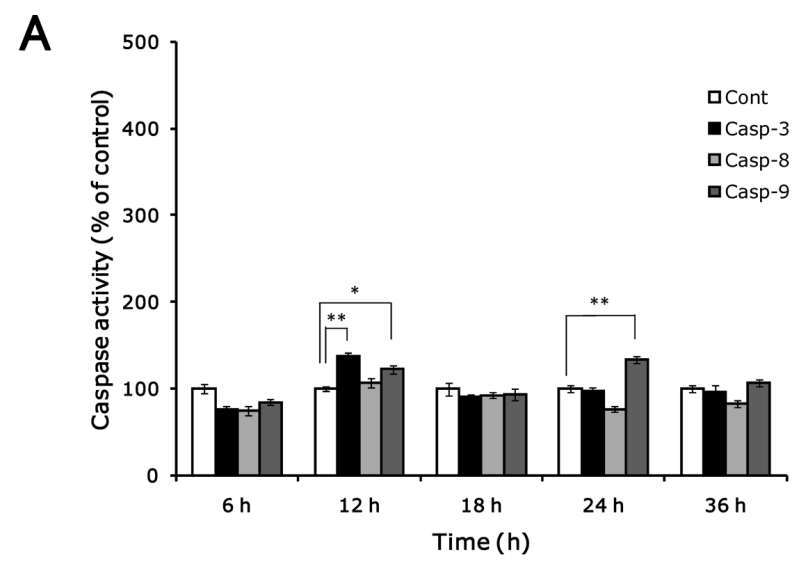

B

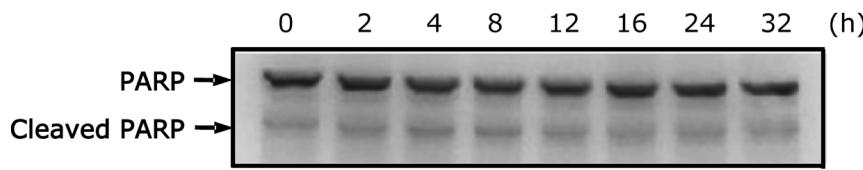

$\beta$-Actin

Fig. 3. Effects of Harmol Treatment on Caspase Activity and Cleavage of PARP in A549 Cells

(A) The activities of caspase-3, caspase-8, and caspase-9 in A549 cells were measured as described in Materials and Methods. Each value is expressed as mean \pm S.D. based on three independent experiments. The asterisks $(*)$ and $(* *)$ indicate a significant difference between non-treated control cells and harmol-treated cells $[(p<0.05)$ and $(p<0.01)]$, respectively. (B) After treatment with $70 \mu \mathrm{M}$ harmol for the indicated times, PARP cleavage was examined by Western blot analysis. 
for 24 and $48 \mathrm{~h}$ induced growth inhibition and cell death in a time- and dose-dependent manner (Fig. 2). The cell viabilities of A549 cells exposed to harmol at various concentrations of $20,40,60,80$, and $100 \mu \mathrm{M}$ in triplicate for $24 \mathrm{~h}$ were $102.3 \%, 91.8 \%, 81.5 \%, 74.6 \%$, and $68.9 \%$, respectively. After treatment with harmol for $48 \mathrm{~h}$, the cell viabilities decreased to $78.8 \%, 62.6 \%, 42.6 \%, 28.8 \%$, and $14.5 \%$, respectively (Fig. 2). Subsequent experiments were carried out at a concentration of $70 \mu \mathrm{m}$ harmol in which cell death was clearly observed in the 24-h treatment.

Changes in Caspase Activities and Poly-(ADP-ribose)polymerase Cleavage To confirm whether the cell death induced by harmol treatment was due to apoptosis, the activities of 3 types of caspase were examined (Fig. 3A). Harmol showed no noticeable effect on the activities of these caspases, although some weak elevations of caspase activities were observed. We also examined the effects of harmol on PARP cleavage. PARP is a key participant in DNA base excision repair and in maintaining genome integrity. ${ }^{26)}$ PARP is well known as an endogenous substrate for caspase-3 and an early marker of apoptosis. ${ }^{26,27)}$ After treatment with $70 \mu \mathrm{M}$ harmol for $2-32 \mathrm{~h}$, the content of the intact form $(116 \mathrm{kDa})$ of PARP did not decrease, and the cleaved form of PARP (89 kDa) did not appear (Fig. 3B). These data suggest that apoptosis is not a major cause of cell death in A549 cells.

Formation of Autophagic Vacuoles by Treatment with Harmol Phase contrast microscopy of harmol-treated A549 cells showed intense vacuoles (Fig. 4: left side, middle and lower panels). Based on the above findings, we would

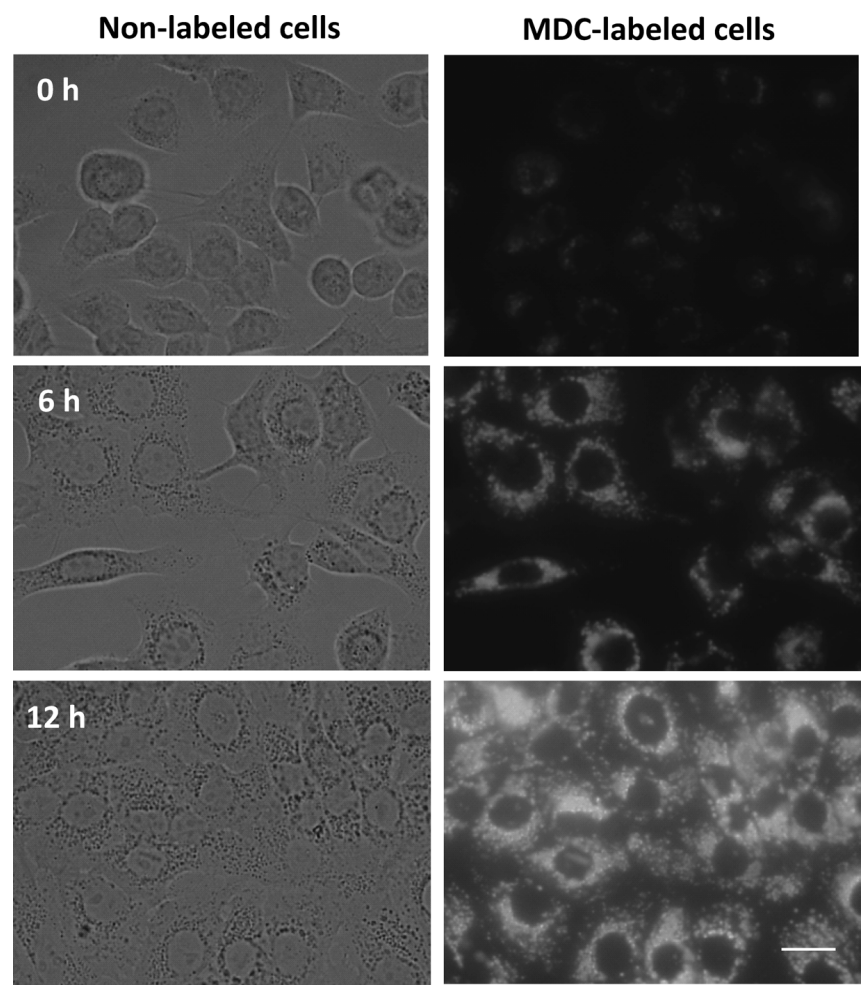

Fig. 4. Harmol-Induced Vacuolization and Formation of MDC-Labeled Vesicles in A549 Cells

(Left panel) A549 cells were treated or not treated with $70 \mu \mathrm{M}$ harmol for $0-12 \mathrm{~h}$ before phase contrast microscopy; (right panel) after treatment with $70 \mu \mathrm{M}$ harmol for the indicated times, the cells were further incubated with $25 \mu \mathrm{M}$ MDC for $10 \mathrm{~min}$. Then, the cells were washed twice with PBS and immediately analyzed by fluorescence microscopy. (Scale bar: $20 \mu \mathrm{m}$ ) expect these intense vacuoles to be formed on harmol treatment, which were not detected in untreated cell autophagosomes. The fluorescent compound MDC is a specific marker for autolysosomes, ${ }^{28}$ ) and is commonly used to stain autophagic vesicles. We studied the incorporation of MDC in cells where autophagy was stimulated by harmol treatment. A549 cells were treated with $70 \mu \mathrm{M}$ harmol for $0-12 \mathrm{~h}$ and then analyzed by fluorescence microscopy. As shown in Fig. 4 (right side, upper panel), in control cells ( $0 \mathrm{~h}$ treatment), MDC-labeled vacuoles were partially detected. However, in 6-h treatment cells, MDC-labeled fluorescent dots were clearly detected, and the number of these dots increased during treatment in a time-dependent fashion (Fig. 4: right side, middle and lower panels). Although MDC-labeled fluorescent dots were observed in harmol-treated A549 cells, we performed electron microscopy to obtain ultrastructural information regarding the morphology of harmol-induced autophagy in A549 cells. Figure 5 shows an electron micrograph of a non-treated A549 cell (upper panel) and an A549 cell treated with harmol (lower panel). The electron micrograph of the harmol-treated A549 cell showed numerous cy-

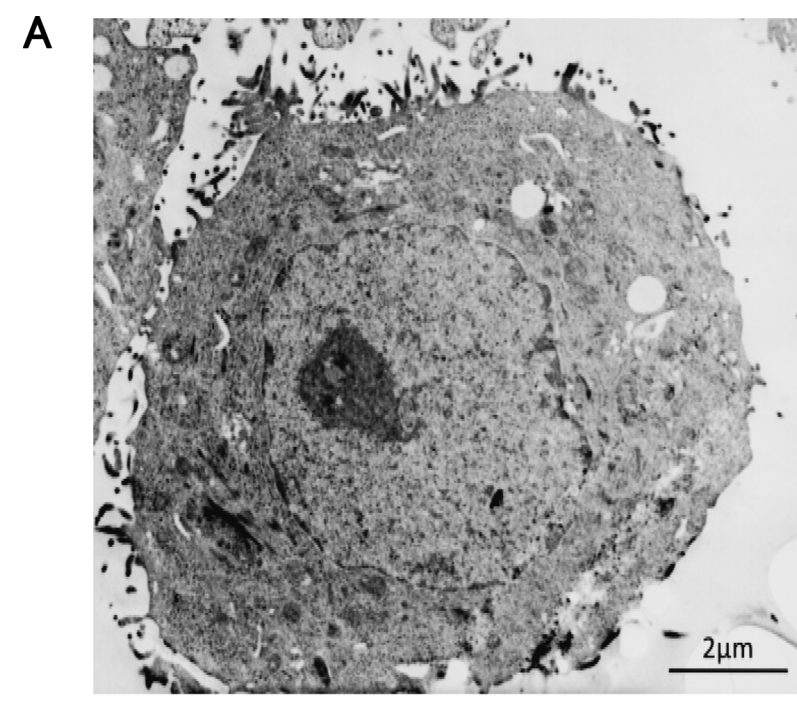

B

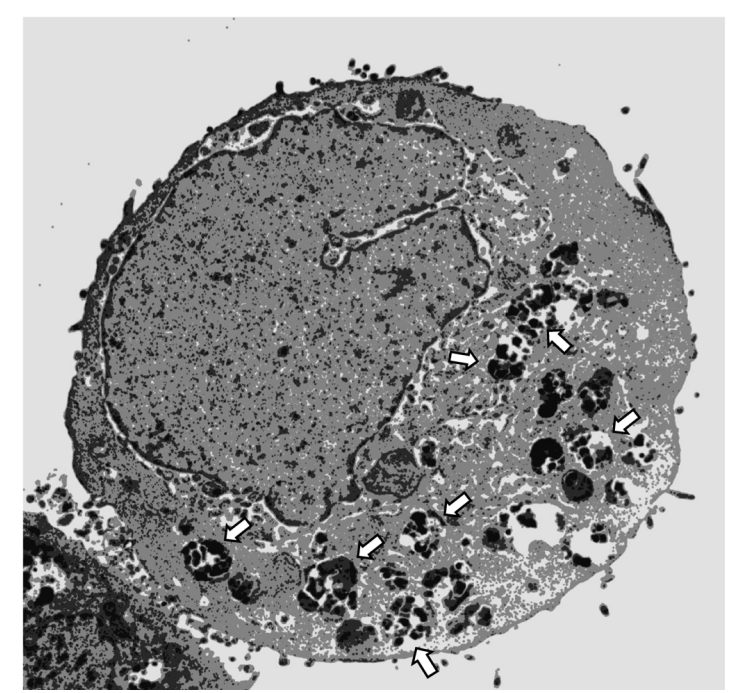

Fig. 5. Electron Micrographs of Harmol-Treated A549 Cells

(A) Non-treated control cells. (B) A549 cells were treated with $70 \mu \mathrm{M}$ harmol for $12 \mathrm{~h}$. 
toplasmic phagolysosomes that contained highly electrondense materials and dispersed chromatin in the nucleus, and the cell surface was characterized by the loss of microvilli (Fig. 5, lower panel). On the other hand, few phagolysosomes were observed in the control cell (Fig. 5, upper panel).

Quantitative Detection of Microtubule-Associated Protein 1 Light Chain 3 (LC3) To quantify the incidence of harmol-induced autophagy, we examined the expression of LC3-I and LC3-II proteins using Western blot analysis, as these proteins are essential in the formation of autophagosomes (especially LC3-II) and have been widely used for estimating the number of autophagosomes or incidence of autophagy. ${ }^{29)}$ The expression of LC3-II in harmol-treated cells was detected within $2 \mathrm{~h}$, and increased during treatment in a

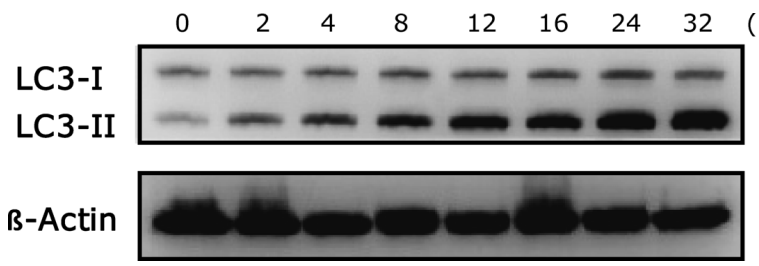

Fig. 6. Chronological Course of Autophagy Induction by Harmol

A549 cells were treated with $70 \mu \mathrm{M}$ harmol for the indicated times. Autophagy in duction was evaluated by the detection of LC3-II protein accumulation. The levels of LC3-I and LC3-II proteins were determined by Western blot analysis with anti-LC3 antibody. The amount of protein loaded in each lane was assessed by stripping and reprobing with a $\beta$-actin antibody.

\section{A}

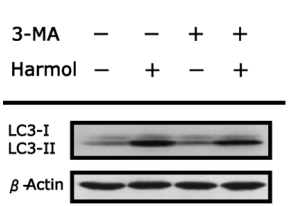

B

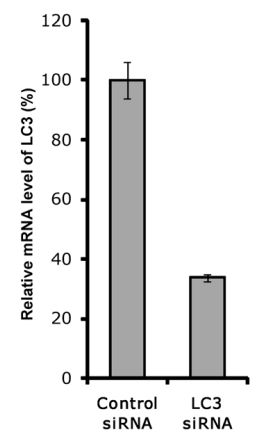

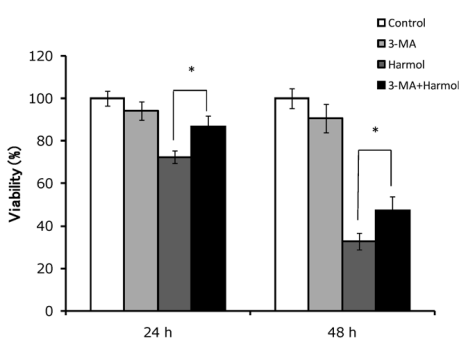

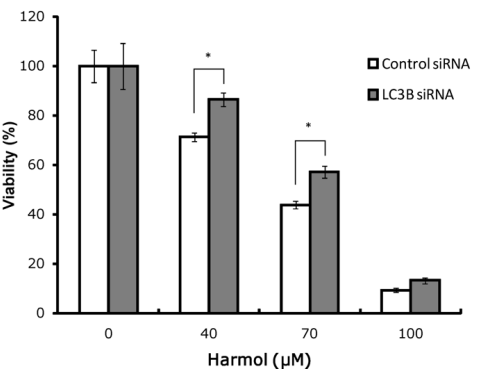

Fig. 7. Effects of 3-MA and siRNA on LC3 Knockdown in Harmol Cytotoxicity

(A) A549 cells were pretreated with $2.5 \mathrm{~mm} 3$-MA for $1 \mathrm{~h}$ before the addition of $70 \mu \mathrm{m}$ harmol for an additional incubation of $24-48 \mathrm{~h}$. Viability was assessed as described in Materials and Methods. The data shown are the means from three independent experiments. Each value is expressed as mean \pm S.D. of three determinations. The asterisks $(*)$ indicate a significant difference between harmol-treated cells and 3-MA with harmol-treated cells $(p<0.05)$. In addition, cellular proteins of 48 -h treatment samples were lysed and subjected to Western blot analysis with anti-LC3 antibody. (B) A549 cells were pretreated with either siRNA for LC3 or control scramble siRNA for $24 \mathrm{~h}$ and subsequently treated with harmol at various concentrations for $24-48 \mathrm{~h}$. Viability was assessed as described in Materials and Methods. LC3 mRNA levels were quantified by real-time RT-PCR. Viability was assessed as described in Materials and Methods. The asterisks $(*)$ indicate a significant difference between harmol-treated cells and 3-MA with harmol-treated cells $(p<0.01)$. time-dependent manner (Fig. 6). Taken together, these results also suggest that harmol induced autophagy in A549 cells.

Role of Autophagy in Harmol-Mediated Cell Death Autophagy plays an important role in the regulation of cell survival or death.,6) To determine whether the induction of autophagy by harmol is a survival or death mechanism, we investigated the effects of harmol on cell survival in the presence of an autophagy inhibitor in A549 cells. As shown in Fig. 7A, 3-MA, a specific inhibitor of the early-stage autophagic process, ${ }^{30)}$ suppressed the expression of LC3 protein and harmol-induced cell death in A549 cells. Furthermore, the suppression of autophagy by siRNA-mediated knockdown of LC3 in A549 cells also attenuated harmolinduced cell death (Fig. 7B).

Harmol-Induced Autophagy Is Independent on the Mammalian Target of Rapamycin Pathway Our next objective was to identify and characterize the molecular pathways involved in harmol-induced autophagy. The classical pathway that regulates autophagy involves the serine/threonine kinase, mTOR. ${ }^{30)}$ The Akt/mTOR/P70S6K, 4E-BP1 pathway is the main regulatory pathway that negatively regulates autophagy. However, several pathways appear to regulate autophagy in mammalian cells. Thus, we investigated whether the autophagy induced by harmol is mediated by an mTOR-dependent or independent pathway using Western blot analysis (Fig. 8). Treatment with harmol did not affect the phosphorylation of Akt (either Ser473 or Thr308), but

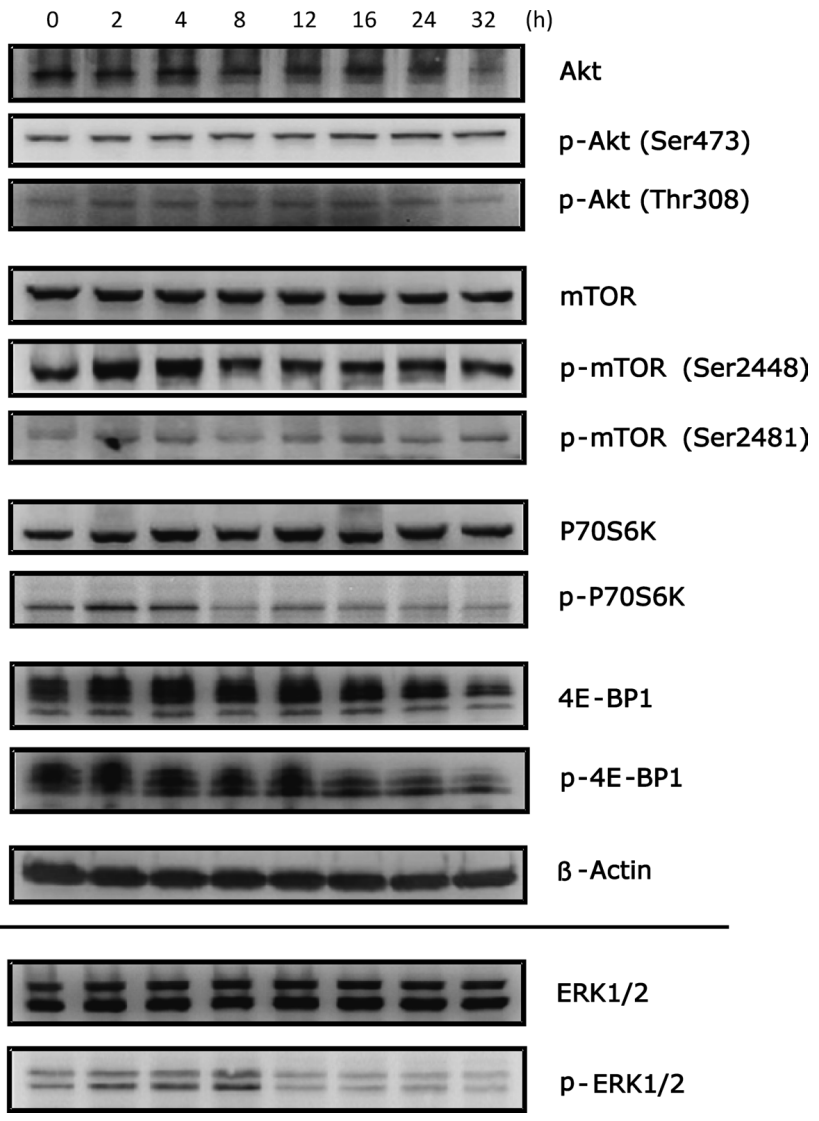

Fig. 8. Harmol Did Not Affect the Akt/mTOR Pathway, but Activated the ERK1/2 Pathways in A549 Cells

A549 cells were treated with $70 \mu \mathrm{M}$ harmol for the indicated times, and then subjected to Western blot analysis. The amount of protein loaded in each lane was assessed by stripping and reprobing with a $\beta$-actin antibody. 


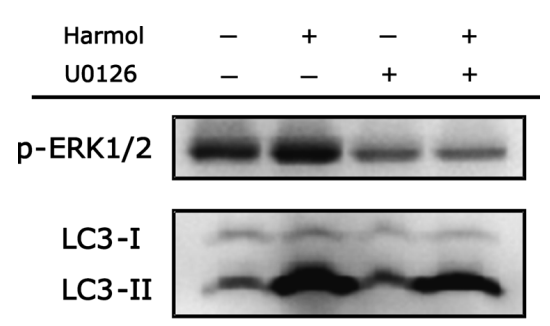

B-Actin

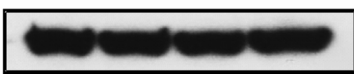

Fig. 9. Inhibition of the ERK Pathway by U0126

A549 cells were pretreated with $15 \mu \mathrm{M} \mathrm{U} 0126$ for $1 \mathrm{~h}$, and then co-treated with $70 \mu \mathrm{M}$ harmol and $15 \mu \mathrm{M}$ U0126 for an additional $6 \mathrm{~h}$. After treatment, equal amounts of whole-cell extracts were separated by SDS-polyacrylamide gel electrophoresis, and the levels of p-ERK1/2 and LC3 proteins were determined by Western blot analysis with these antibodies. The amount of protein loaded in each lane was assessed by stripping and reprobing with a $\beta$-actin antibody.

slightly increased the level of phospho-mTOR (Ser2448) (pmTOR) for 2 to $4 \mathrm{~h}$, and then decreased to the baseline level. Examination of the phosphorylation of 2 downstream effectors of mTOR signaling, P70S6K and 4E-BP1, showed that both p-P70S6K and p-4E-BP1 transiently and slightly increased for 2 to $4 \mathrm{~h}$, and then decreased. As the ERK pathway positively regulates autophagy in cancer cells on starvation, ${ }^{31)}$ we also tested this pathway after treatment with harmol. After treating the cells with harmol, the level of $\mathrm{p}$ ERK1/2 increased for 2 to $8 \mathrm{~h}$, and then decreased.

Effects of the MEK1/2 and ERK1/2 Inhibitor U0126 on Harmol-Treated Cells To determine whether ERK phosphorylation was closely related to harmol-induced autophagy, we treated A549 cells with U0126, as a MEK1/2 and ERK1/2 inhibitor. We tested A549 cells treated with harmol in the absence and presence of U0126, and then detected the levels of p-ERK1/2 and LC3-II. As shown in Fig. 8, harmol treatment increased the expression levels of p-ERK $1 / 2$ and LC3-II. However, in cells which were treated with both harmol and U0126, although the expression of p-ERK1/2 was strongly suppressed, that of LC3-II slightly decreased (Fig. 9).

\section{DISCUSSION}

We previously reported that harmol has apoptosis-inducing effects in human NSCLC H596 cells through the caspase-8-dependent pathway, but independent of the Fas/Fas ligand interaction. ${ }^{25)}$ Apoptosis occurs by 2 major different activation pathways (the intrinsic and extrinsic pathways). ${ }^{31,32)}$ In the intrinsic pathway, the diverse stimuli that provoke cell stress or damage typically activate one or more members of the BH3-only protein family, leading to the release of cytochrome $c$. Cytochrome $c$ then binds to apoptosis-activating factor 1 and procaspase-9, resulting in the activation of caspase- 9 by proteolytic cleavage. The extrinsic pathway starts with death receptor ligation or Fas/Fas ligand interaction, followed by oligomerization of the receptor, use of Fas-associated death domain (FADD) protein, and activation of caspase- $8 .{ }^{33)}$ Caspase- 8 and caspase- 9 have been generally defined as initiator caspases, and can in turn activate caspase-3, the executor of apoptosis. ${ }^{34,35)}$ In the present study, harmol induced cell death in human lung adenocarcinoma
A549 cells. However, harmol treatment did not induce caspase-3, caspase-8, and caspase-9 activation or PARP cleavage (Figs. 3A, B). These results indicate that the harmol-induced cell death in A549 cells was not apoptosis. The reason for the difference between H596 and A549 cells on harmol treatment was unclear. Several pro-apoptotic signals induce autophagy (e.g., components of the extrinsic apoptosis pathway, tumor necrosis factor (TNF), TNF related apoptosis-inducing ligand (TRAIL), FADD, and ceramide). ${ }^{36-42)}$ On the other hand, anti-apoptotic signaling pathways suppress autophagy (e.g., class I phosphatidylinositol 3-kinase (PI3K)/ Akt/mTOR signaling pathway). ${ }^{30,43,44)}$ Therefore, it is thought that similar stimuli can induce either apoptosis or autophagy. Furthermore, a mixed phenotype of autophagy and apoptosis can sometimes be detected in response to these common stimuli. ${ }^{45}$ Therefore, harmol treatment may induce autophagy not only in A549 cells but also in H596 cells. Rapid apoptosis induction in $\mathrm{H} 596$ cells, which was clearly detected within $3 \mathrm{~h}$ of treatment with harmol, might mask the induction of autophagy. If we had observed H596 cells with a higher expression of anti-apoptotic proteins such as Bcl-2 or survivin, autophagy induction in response to harmol might be detected. Regarding with A549 cell lines, Ogura et al. reported that X-irradiation of wild-type A549 cells did not induce apoptosis. However, when A549 cells, (which overexpress survivin mutant protein) were exposed to X-rays, apoptosis was induced. ${ }^{46}$ ) Therefore, in this study, the possibility remains that survivin inhibited apoptosis induction in A549 cells. Additional experiments are required to clarify this mechanism.

Autophagy is a genetically regulated program, initially identified as a cell survival mechanism to protect against nutrient deprivation. However, in certain conditions, autophagy results in a form of cell death presently described as type II PCD. ${ }^{4,9)}$ Some types of cancer exhibit autophagic changes after treatments with various anticancer agents. ${ }^{47-50)} \mathrm{Au}-$ tophagic cell death is characterized by numerous autophagic vacuoles in the cytoplasm, ${ }^{5,6}$ whereas the nucleus remains intact until the late stage of cell death. However, apoptosis is characterized by DNA condensation and fragmentation. Electron microscopic analysis showed that the number of autophagic vacuoles containing cellular materials increased in A549 cells treated with harmol for $12 \mathrm{~h}$, compared with nontreated control cells; however, nuclear condensation was not detected in the harmol-treated A549 cells (Fig. 5). These findings indicate that harmol treatment induced autophagy but not apoptosis in A549 cells.

LC3 plays a critical role in autophagy formation and is considered a suitable marker for this process. LC3 exists in the cytosolic form (pro-form) and the carboxyl terminal of nascent LC3 is cleaved off by the Atg4 protease to become LC3-I. When autophagy is induced, the newly exposed carboxyl terminal of glycine residue in LC3-I is modified with phosphatidylethanolamine, generating autophagosomal membrane-bound LC3-II. ${ }^{29)}$ In the present study, harmol increased the expression of LC3-I and LC3-II in A549 cells after just $2 \mathrm{~h}$ of treatment, and this expression further increased with treatment in a time-dependent fashion (Fig. 6).

To investigate whether autophagy induced by harmol has cytoprotective function or leads to cell death (i.e., autophagic cell death), we treated A549 cells with harmol in the pres- 
ence or absence of 3-MA (Fig. 7A). The 3-MA, a specific inhibitor of the early-stage autophagic process, is often used in autophagy studies. However, in A549 cells, 3-MA showed strong cytotoxicity at concentrations of up to $2.5 \mathrm{~mm}$ for partially attenuating autophagy (data not shown). Therefore, we performed an autophagy suppression experiment with 3-MA at $2.5 \mathrm{~mm}$. However, treatment with $2.5 \mathrm{~mm} 3-\mathrm{MA}$ partially suppressed both LC3 expression and the cytotoxic effect (Fig. 7A). Similarly, the suppression of autophagy by siRNAmediated knockdown of LC3 in A549 cells partially suppressed both the harmol-induced cell death and the mRNA levels of LC3 (Fig. 7B). Therefore, to further improve the rate of harmol-induced cell death, complete inhibition of autophagy may be required.

Autophagy is regulated by multiple signaling pathways as diverse as the GTPase $\mathrm{G}_{\mathrm{i} 3}$, the class III PI3K, and the protein kinases mTOR, ERK, and p38. ${ }^{51)}$ In particular, the $\mathrm{Akt} / \mathrm{mTOR}$ and ERK1/2 pathways are 2 major pathways that regulate autophagy-induced nutrient starvation. The Akt/mTOR pathway negatively regulates autophagy ${ }^{52)}$ and the ERK1/2 pathway positively regulates autophagy. ${ }^{53,54)}$ These pathways are also frequently associated with oncogenesis. Several studies have shown that the inhibition of Akt phosphorylation and its downstream mTOR signaling target contribute to the initiation of autophagy. ${ }^{30,55-57)}$ However, Fig. 8 clearly shows that harmol treatment did not affect the phosphorylation of Akt (neither Ser473 nor Thr 308), but the level of p-mTOR (Ser2448), downstream from Akt, transiently increased for 2 to $4 \mathrm{~h}$, and then decreased to the control level. Similarly, the levels of p-P70S6K and p-4E-BP1, downstream targets of mTOR, also transiently increased and then decreased. Therefore, in an early stage of autophagy induction, it appeared that the Akt/mTOR pathway was not related to autophagy in the present study. It is reported that Bcl-2, Beclin-1, and AMP activated protein kinase (AMPK) are also involved in autophagy induction. Lines of evidence to support an AMPK role in autophagy induction in response to various cellular stress conditions (e.g., low glucose level, hypoxia, heat shock, and ischemia) are increasing. ${ }^{58-62)} \mathrm{Al}$ though the exact molecular mechanism underlying autophagy regulation by AMPK is unknown, it is assumed that AMPK stimulates autophagy by inhibiting mTOR complex 1 (mTORC1) at the level of tuberous sclerosis complex 2 $(\mathrm{TSC} 2)^{63)}$ and the regulatory associated protein of mTOR (Raptor). ${ }^{64)}$ Inhibition of mTORC 1 , which is located upstream of the mTOR pathway, negatively regulated the mTOR pathway. However, in the present study, harmol treatment did not affect the mTOR pathway (Fig. 8). Therefore, it is considered that AMPK is not related to the harmol-induced autophagy. In mammalian cells, Bcl-2 family members in the outer mitochondrial membrane modulate autophagy. Bcl-2 downregulation increases autophagy in a caspase-independent manner in human leukemic cells, ${ }^{65)}$ and its overexpression inhibits both autophagy and caspase-independent death in growth factor-deprived neural progenitor cells and in serum- and potassium-deprived cultured cerebellar granule cells. $^{66,67)}$ Furthermore, it is reported that imatinib induces autophagy in chronic myeloid leukemia cells by inducing the overexpression of Beclin-1. ${ }^{68)}$ However, in the Western blot analysis of harmol-treated A549 cells, changes in the protein expression and phosphorylation levels of Bcl-2 and Beclin-1 were not observed (data not shown).

Recently, there has been an increasing number of studies showing that the activation of the ERK1/2 pathway induces autophagy. ${ }^{69,70)}$ In the current results, harmol treatment also induced the phosphorylation of ERK1/2 within $2 \mathrm{~h}$ in A549 cells (Fig. 8). However, in A549 cells which were treated with harmol in the presence of U0126, a MEK/ERK1/2 inhibitor, p-ERK1/2 expression was suppressed completely, but LC3-II expression was only partially inhibited (Fig. 9). From these results, we considered that harmol-induced autophagy is related to the ERK pathway, but is only partially dependent. Therefore, another main pathway may also be involved in the autophagy induction process of harmol. Further studies are needed to determine precisely the underlying mechanism of this pathway.

$\beta$-Carbolines occur naturally as harmala alkaloids in $\mathrm{Pe}$ ganum harmala LinNÉ, which are also widely found in other medicinal plants, ${ }^{18,19)}$ and are found endogenously in mammalian tissues. ${ }^{71,72}$ ) Harmala alkaloids have been used in some hallucinogenic preparations of South American and African tribes. ${ }^{73}$ Furthermore, plants containing harmala alkaloids have long been used in traditional medicine to treat asthma, jaundice, lumbago, and other ailments. ${ }^{19-21)}$ Certain $\beta$-carboline alkaloids have a wide spectrum of neuropharmacological and psychopharmacological actions on the central nervous system such as tremorogenesis, ${ }^{74,75)}$ hypothermia, ${ }^{76}$ hallucinogenesis, ${ }^{77,78)}$ monoamine oxidase (MAO) inhibition, ${ }^{79,80)}$ and convulsive or anticonvulsive actions. ${ }^{81)}$ The central nervous effects of $\beta$-carbolines mainly depend on $\beta$ carbolines which have a methoxyl group at the C-7 position in their structures. Therefore, $\beta$-carbolines which have a methoxyl group at the C-7 position are not suitable for chemotherapeutic agents. $\beta$-Carbolines such as harmol, which have a hydroxyl group at the C-7 position (Fig. 1), have slight or no MAO-inhibiting effects ${ }^{80,82)}$ and neuropharmacological effects, such as convulsion. ${ }^{83)}$ With regard to the metabolic pathway, harmol is conjugated with sulfate and excreted in urine and bile, and it has a fast rate of urinary excretion in humans after intravenous administration. ${ }^{84)}$ Therefore, it is considered that harmol has low toxicity in humans and animals.

In conclusion, we have shown for the first time that harmol induces autophagic cell death in lung carcinoma A549 cells. As this effect of harmol was investigated only in NSCLC, its effect on other types of cancer should also be examined. Furthermore, although additional investigation is needed to precisely clarify the autophagy induction pathway, it is thought to be a candidate pathway that can be targeted by a chemotherapeutic agent in cancer treatment.

Acknowledgements The authors are indebted to $\mathrm{Mr}$. Roderick J. Turner, Assistant Professor Edward F. Barroga and Professor J. Patrick Barron, Chairman of the Department of International Medical Communications at Tokyo Medical University for their review of this manuscript.

\section{REFERENCES}

1) Lokshin A., Levitt M. L., J. Cell. Biochem., 24 (Suppl.), S186-S197 (1996).

2) Wang H., Rayburn E. R., Wang W., Kandimalla E. R., Agrawal S., 
Zhang R., Mol. Cancer Ther, 5, 1585-1592 (2006).

3) Linnoila R. I., J. Cell. Biochem., 24 (Suppl.), 92-106 (1996).

4) Clarke P. G., Anat. Embryol. (Berlin), 181, 195-213 (1990).

5) Klionsky D. J., Emr S. D., Science, 290, 1717-1721 (2000).

6) Levine B., Klionsky D. J., Dev. Cell, 6, 463-477 (2004).

7) Levine B., Yuan J., J. Clin. Invest., 115, 2679-2688 (2005).

8) Shintani T., Klionsky D. J., Science, 306, 990-995 (2004).

9) Gozuacik D., Kimchi A., Oncogene, 23, 2891-2906 (2004).

10) Debnath J., Baehrecke E. H., Kroemer G., Autophagy, 1, 66-74 (2005).

11) Nelson D. A., White E., Genes Dev., 18, 1223-1226 (2004).

12) Edinger A. L., Thompson C. B., Curr. Opin. Cell Biol., 16, 663-669 (2004).

13) Mizushima N., Levine B., Cuervo A. M., Klionsky D. J., Nature (London), 451, 1069-1075 (2008).

14) Ogier-Denis E., Codogno P., Biochim. Biophys. Acta, 1603, 113-128 (2003).

15) Corcelle E., Nebout M., Bekri S., Gauthier N., Hofman P., Poujeol P., Fénichel P., Mograbi B., Cancer Res., 66, 6861 -6870 (2006).

16) Otsuka H., Moskowitz M., Exp. Cell Res., 112, 127-135 (1978).

17) Kirkegaad K., Taylor M. P., Jacson W. T., Nat. Rev. Microbiol., 2, 301-314 (2004).

18) List P. H., Hörhammer L., "Hager's Handbook for Pharmaceutical Practice," Springer-Verlag, Berlin, 1970.

19) Naranjo C., "Psychotropic Properties of the Harmala Alkaloids," ed by Efron D. H., Holmested B., Kline N. S., Ethnopharmacological Search for Psychoactive Drugs, U.S. Public Health Service, New York, 1967, pp. 385-392.

20) Nadikarni K. M., "Indian Material Medica," Vol. 1, Popular Pakistan Limited, Bombay, 1976, pp. 927-929.

21) Dymock W., Warden C. J., Hooper D., "Pharmacopia Indica," Vol. 1, Harmad National Foundation of Pakistan, Pakistan, 1976, pp. 252253.

22) Sobhani A. M., Ebrahimi S. A., Mahmoudian M., J. Pharm. Pharm. Sci., 5, 19-23 (2002).

23) Lamchouri F., Settaf A., Cherrah Y., Zemzami M., Lyoussi B., Zaid A., Atif N., Hassar M., Therapie, 54, 753-758 (1999).

24) Kuo P. C., Shi L. S., Damu A. G., Su C. R., Huang C. H., Ke C. H., Wu J. B., Lin A. J., Bastow K. F., Lee K. H., Wu T. S., J. Nat. Prod., 66, 1324-1327 (2003)

25) Abe A., Yamada H., Anticancer Drugs, 20, 373-381 (2009).

26) Simbulan-Rosenthal C. M., Rosenthal D. S., Iyer S., Boulares H., Smulson M. E., Mol. Cell. Biochem., 193, 137-148 (1999).

27) Green D. R., Reed J. C., Science, 281, 1309-1312 (1998).

28) Biederbick A., Kern H. F., Elsässer H. P., Eur. J. Cell Biol., 66, 3-14 (1995).

29) Kabeya Y., Mizushima N., Ueno T., Yamamoto A., Kirisako T., Noda T., Kominami E., Ohsumi Y., Yoshimori T., EMBO J., 19, 5720-5728 (2000).

30) Rubinsztein D. C., Gestwicki J. E., Murphy L. O., Klionsky D. J., Nat. Rev. Drug Discov., 6, 304-312 (2007).

31) Green D. R., Cell, 94, 695-698 (1998).

32) Ashkenazi A., Dixit V. M., Science, 281, 1305-1308 (1998)

33) Gross A., Yin X. M., Wang K., Wei M. C., Jockel J., Milliman C., Erdjument-Bromage H., Tempst P., Korsmeyer S. J., J. Biol. Chem., 274, 1156-1163 (1999).

34) Zha J., Weiler S., Oh K. J., Wei M. C., Korsmeyer S. J., Science, 290, $1761-1765$ (2000).

35) Shao R. G., Cao C. X., Nieves-Neira W., Dimanche-Boitrel M. T., Solary E., Pommier Y., Oncogene, 20, 1852-1859 (2001).

36) Jia L., Dourmashkin R. R., Allen P. D., Gray A. B., Newland A. C., Kelsey S. M., Br. J. Haematol., 98, 673-685 (1997).

37) Mills K. R., Reginato M., Debnath J., Queenan B., Brugge J. S., Proc. Natl. Acad. Sci. U.S.A., 101, 3438-3443 (2004).

38) Thorburn J., Moore F., Rao A., Barclay W. W., Thomas L. R., Grant K. W., Cramer S. D., Thorburn A., Mol. Biol. Cell, 16, 1189-1199 (2005).

39) Prins J., Ledgerwood E., Ameloot P., Vandenabeele P., Faraco P., Bright N., O'Rahilly S., Bradley J., Biochem. Soc. Trans., 26, S316 (1998).

40) Pyo J. O., Jang M. H., Kwon Y. K., Lee H. J., Jun J. I., Woo H. N., Cho D. H., Choi B., Lee H., Kim J. H., Mizushima N., Oshumi Y., Jung Y. K., J. Biol. Chem., 280, 20722-20729 (2005).

41) Scarlatti F., Bauvy C., Ventruti A., Sala G., Cluzeaud F., Vandewalle
A., Ghidoni R., Codogno P., J. Biol. Chem., 279, 18384-18391 (2004).

42) Daido S., Kanzawa T., Yamamoto A., Takeuchi H., Kondo Y., Kondo S., Cancer Res., 64, 4286-4293 (2004).

43) Lum J. J., DeBerardinis R. J., Thompson C. B., Nat. Rev. Mol. Cell Biol., 6, 439-448 (2005)

44) Meijer A. J., Codogno P., Int. J. Biochem. Cell Biol., 36, 2445-2462 (2004).

45) Maiuri C. M., Zalckvar E., Kimchi A., Kroemer G., Mol. Cell. Biol., 8, $741-752$ (2007).

46) Ogura A., Watanabe Y., Iizuka D., Yasui H., Amitani M., Kobayashi S., Kuwabara M., Inanami O., Cancer Lett., 259, 71—81 (2008).

47) Kim E. H., Sohn S., Kwon H. J., Kim S. U., Kim M. J., Lee S. J., Choi K. S., Cancer Res., 67, 6314-6324 (2007).

48) Gao M., Yeh P. Y., Lu Y. S., Hsu C. H., Chen K. F., Lee W. C., Feng W. C., Chen C. S., Kuo M. L., Cheng A. L., Cancer Res., 68, 9348—9357 (2008).

49) Bilia A., Altinoz M. A., Erkan M., Ozmen V., Aydiner A., Pathobiology, 69, 120-126 (2001)

50) Kanzawa T., Germano I. M., Komata T., Ito H., Kondo Y., Kondo S., Cell Death Differ., 11, 448 - 457 (2004).

51) Petiot A., Pattingre S., Arico S., Meley D., Codogno P., Cell Struct. Funct., 27, 431-441 (2002).

52) Shinojima N., Yokoyama T., Kondo Y., Kondo S., Autophagy, 3, 635637 (2007)

53) Ogier-Denis E., Pattingre S., EI Benna J., Codongo P., J. Biol. Chem., 275, 39090-39095 (2000).

54) Pattingre S., Bauvy C., Codogno P., J. Biol. Chem., 278, 16667$16674(2003)$

55) Iwamaru A., Kondo Y., Iwado E., Aoki H., Fujiwara K., Yokoyama T., Mills G. B., Kondo S., Oncogene, 26, 1840-1851 (2007).

56) Kim K. W., Mutter R. W., Cao C., Albert J. M., Freeman M., Hallahan D. E., Lu B., J. Biol. Chem., 281, 36883-36890 (2006).

57) Easton J. B., Houghton P. J., Oncogene, 25, 6436-6446 (2006).

58) Vingtdeux V., Giliberto L., Zhao H., Chandakkar P., Wu Q., Simon J. E., Janle E. M., Lobo J., Ferruzzi M. G., Davies P., Marambaud P., J. Biol. Chem., 285, 9100-9113 (2010).

59) Herrero-Martín G., Høyer-Hansen M., García-García C., Fumarola C., Farkas T., López-Rivas A., Jäättelä M., EMBO J., 28, 677-685 (2009).

60) Matsui Y., Takagi H., Qu X., Abdellatif M., Sakoda H., Asano T., Levine B., Sadoshima J., Circ. Res., 100, 914-922 (2007).

61) Liang J., Shao S. H., Xu Z. X., Hennessy B., Ding Z., Larrea M., Kondo S., Dumont D. J., Gutterman J. U., Walker C. L., Slingerland J. M., Mills G. B., Nat. Cell Biol., 9, 218-224 (2007).

62) Meley D., Bauvy C., Houben-Weerts J. H., Dubbelhuis P. F., Helmond M. T., Codogno P., Meijer A. J., J. Biol. Chem., 281, 34870-34879 (2006).

63) Inoki K., Zhu T., Guan K. L., Cell, 115, 577—590 (2003).

64) Gwinn D. M., Shackelford D. B., Egan D. F., Mihaylova M. M., Mery A., Vasquez D. S., Turk B. E., Shaw R. J., Mol. Cell, 30, 214-226 (2008).

65) Saeki K., Yuo A., Okuma E., Yazaki Y., Susin S. A., Kroemer G., Takaku F., Cell Death Differ., 7, 1263-1269 (2000).

66) Canu N., Tufi R., Serafino A. L., Amadoro G., Ciotti M. T., Calissano P., J. Neurochem., 92, 1228-1242 (2005).

67) Cardenas-Aguayo Mdel. C., Santa-Olalla J., Baizabal J. M., Salgado L. M., Covarrubias L., J. Hematother. Stem Cell Res., 12, 735-748 (2003).

68) Can G., Ekiz H. A., Baran Y., Hematology, 16, 95-99 (2011).

69) Ellington A. A., Berhow M. A., Singletary K. W., Carcinogenesis, 27, 298-306 (2006).

70) Aoki H., Takada Y., Kondo S., Sawaya R., Aggarwal B. B., Kondo Y., Mol. Pharmacol., 72, 29-39 (2007).

71) Airaksinen M. M., Kari I., Mol. Biol., 59, 21-34 (1981).

72) Beck O., Faull K. F., Biochem. Pharmacol., 65, 97-106 (1986).

73) Rommelspacher H., Nanz C., Borbe H. O., Fehske K. J., Müller W. E., Wollert U., Naunyn Schmiedebergs Arch. Pharmacol., 314, 97-100 (1980).

74) Ho B. T., Curr. Dev. Psychopharmacol., 4, 152-177 (1977).

75) Poirier L. J., Sourkes T. L., Bouvier G., Boucher R., Carabin S., Brain, 89, 37-52 (1966).

76) Bruinvels J., Sourkes T. L., Eur. J. Pharmacol., 4, 31-39 (1969).

77) Zetler G., Back G., Iven H., Naunyn Schmiedebergs Arch. Pharmacol., 
285, 273-292 (1974).

78) Grella B., Dukat M., Young R., Teitler M., Herrick-Davis K., Gauthier C. B., Glennon R. A., Drug Alcohol Depend., 50, 99-107 (1998).

79) Udenfriend S., Wiycop B., Redfield B. G., Weissbach H., Biochem. Pharmacol., 1, 160-165 (1958).

80) McIssac W. M., Estevez V., Biochem. Pharmacol., 15, 1625-1627 (1966).
81) Loew G. H., Nienow J., Lawson J. A., Toll L., Uyeno E. T., Mol. Pharmacol., 28, 17-31 (1985).

82) Buckholtz N. S., Boggan W. O., Biochem. Pharmacol., 26, 19911996 (1977).

83) Gunn J. A., Arch. Int. Pharmacodyn., 50, 379-396 (1935).

84) Slotkin T. A., DiStefano V., Au W. Y. W., J. Pharmacol. Exp. Ther, 173, 26-30 (1970) 